\title{
Gonadotrophic activity of the guinea-pig placenta during pregnancy
}

\author{
Elizabeth M. Humphreys, B. M. Hobson* and L. Wide $\dagger$ \\ Departments of Physiology, and *Obstetrics \& Gynaecology, University of Edinburgh, \\ Edinburgh EH8 9AG, U.K. and †Department of Clinical Chemistry, University of Uppsala, \\ Sweden
}

\begin{abstract}
Summary. A gonadotrophic substance was extracted from placentae and subplacentae of guinea-pigs. Biological and immunological assays of these tissues obtained on Days $10-63$ of pregnancy showed the highest mean concentration of the gonadotrophin on Day 18. Extracts chromatographed on Sephadex G200 had components active in the radioimmunoassay system for hCG, hCG-alpha and hCG-beta subunits. The elution profiles of these extracts were similar to those obtained with human term placentae and purified hCG and its subunits. The guinea-pig placental extracts also cross-reacted with an antiserum to the beta subunit of ovine LH, as did hCG. The biological activity of placental and subplacental extracts and of the hCG standard was neutralized by an anti-hCG serum. There is a strong similarity between hCG and the substance extracted from guinea-pig placentae which may therefore have a luteotrophic function similar to that of hCG.
\end{abstract}

\section{Introduction}

In mammals in which the length of gestation exceeds that of the menstrual or oestrous cycle the persistence of a functional corpus luteum is necessary for the establishment of pregnancy. In man and other primates the luteotrophic stimulus is provided by a placental protein hormone chorionic gonadotrophin (CG) (Hobson, 1971). In the pregnant mare a serum gonadotrophin with luteotrophic properties is produced by endometrial cups which are fetal in origin (Catchpole \& Lyons, 1934; Allen \& Moor, 1972).

Earlier attempts to demonstrate a gonadotrophic substance in the placentae of other mammals were generally unsuccessful. However, Astwood \& Greep (1938) provided evidence for an extra-pituitary source of luteotrophin in the pregnant rat which was later referred to as "chorionic gonadotrophin" by Astwood (1953). More recently, extracts or explants from placentae of hamster, mouse, rat and sheep have behaved in a number of biological and non-biological assays in a manner which suggests a similarity between ovine, rodent and human CG (Linkie \& Niswender, 1973; Okker-Reitsma, 1978; Haour, Tell \& Sanchez, 1976; Wide \& Hobson, 1978; Wide \& Wide, 1979; Lacroix \& Martal, 1979; Okker-Reitsma \& Wilson, 1980; Wide, Hobson \& Wide, 1980).

In the guinea-pig the duration of the oestrous cycle is between 16 and 19 days with oestrus lasting on average $8 \mathrm{~h}$ (Phoenix, 1970). The length of gestation varies between 58 and 78 days with a modal duration of 68 days (Blandau \& Young, 1939). Abortion does not occur when hypophysectomy is performed 3-6 days after mating (Heap, Perry \& Rowlands, 1967), or in animals ovariectomized 3-4 weeks post coitum (Herrick, 1928; Courrier, Kehl \& Raynaud, 
1929). Corpora lutea of pregnancy and the production of progesterone in early pregnancy must therefore be maintained by an extra-pituitary source of luteotrophin. Bland \& Donovan (1969) showed that the transfer of conceptuses to, and their subsequent removal from, the uterus of guinea-pigs resulted in first prevention and secondly the recurrence of oestrus, and concluded that a placental hormone, whose nature was unknown, was necessary for continued luteal function and the absence of oestrus. Davies, Dempsey \& Amoroso (1961), using histological, histochemical and electron microscope techniques in an investigation of the development of the guinea-pig subplacenta throughout pregnancy, concluded that this tissue might be the source of a gonadotrophin.

The characteristics of a substance extracted from the placenta and subplacenta of the guinea-pig have been investigated in the present study.

\section{Materials and Methods}

\section{Animals}

Adult nulliparous and multiparous guinea-pigs from a mixed stock were used. They were kept under standardized conditions of heating and lighting and maintained with Labsure Guinea Pig Diet plus hay ad libitum and $100 \mathrm{mg}$ vitamin $\mathrm{C} / 100 \mathrm{ml}$ in the drinking water. Vaginal smears were taken twice daily $(09: 00$ and 16:00 h) and the presence of spermatozoa was taken as evidence that mating had occurred. Day 1 of pregnancy was the day on which spermatozoa were first found in the vaginal smear. Of the 82 pregnant animals used, 66 were nulliparous and 16 multiparous. The number of fetuses in the litters varied between 1 and 9 and the modal number was 4 . All animals were killed by pentobarbitone sodium anaesthesia, and the products of conception were removed and weighed.

\section{Extraction of tissues}

Skeletal muscle, placentae and subplacentae were homogenized in ice-cold acetone $(5 \mathrm{ml} / \mathrm{g})$ and ice-cold ether $(1 \mathrm{ml} / \mathrm{g})$ according to Hobson (1972). The homogenized tissue was kept at $+4{ }^{\circ} \mathrm{C}$ overnight and collected by filtration on a Buchner funnel, washed with an excess of acetone and ether, and dried in a desiccator. This method has been shown to remove steroids present in placental tissue of primates and rodents (Hobson, 1972; Wide \& Hobson, 1978). The dried acetone-ether material, before analysis or assay, was taken up in saline $(9 \mathrm{~g} \mathrm{NaCl} / 1)$, left overnight at $+4^{\circ} \mathrm{C}$, centrifuged, and the supernatant assayed. Depending upon the nature of the investigation the subplacentae and placentae were extracted individually, or were combined before extraction.

\section{Chromatography}

Placentae plus subplacentae from 3 guinea-pigs were extracted, dissolved in saline $(9 \mathrm{~g}$ $\mathrm{NaCl} / \mathrm{l}$ ), pooled and dialysed before chromatography on a $26 \times 930 \mathrm{~mm}$ Sephadex G-200 column, equilibrated with $0.1 \mathrm{M}$-Tris- $\mathrm{HCl}$ buffer of $\mathrm{pH} 7.5$ with $0.2 \mathrm{M}-\mathrm{NaCl}$. The flow was against gravity with a rate of $9 \mathrm{ml} / \mathrm{h}$ and $1003-\mathrm{ml}$ fractions were collected and assayed by solid-phase radioimmunoassays for hCG, hCG alpha and hCG beta subunits. The degree of retardation on the column, expressed in $K_{\mathrm{av}}$ values (Laurent \& Killander, 1964) where $K_{\mathrm{av}}=(\mathrm{Ve}$ - Vo) $/ \mathrm{Vt}-\mathrm{Vo}$ ) and $\mathrm{Ve}$ is the elution volume of the substance, $\mathrm{Vo}$ is the void volume and $\mathrm{Vt}$ is the total bed volume, was compared with that of purified preparations of hCG and its subunits similarly treated. 


\section{Bioassays}

Gonadotrophic activity of placental and subplacental extracts was assayed using the increase in uterine weight of 8-10-g 21-day-old female mice (Schofield Swiss Albino strain) as the index of response. Five mice were used at each of two dose levels, log dose interval 0.301 of the unknown and hCG standard preparations being assayed simultaneously (4-point assays). Some 6-point assays, 3 doses of each of the standard and unknown preparations, were done to compare the linearity of response between the placental extracts and the hCG standard. Estimates of potency of the placental extracts were expressed per $g$ wet weight as International Unit equivalents of the Second International Standard for hCG (i.u. hCG). The smallest amount of hCG which will produce a significance $(P<0.01)$ response in the bioassay, compared with saline-injected controls, is 0.0625 i.u. The level of gonadotrophic activity in guinea-pig skeletal muscle is less than the equivalent of 0.087 i.u. $\mathrm{hCG} / \mathrm{g}$ fresh weight of tissue.

\section{Radioimmunoassay}

The immunoreactivities of the saline extracts, before and after chromatography, were assayed by solid-phase radioimmunoassays (Wide, 1969) for hCG, hCG-alpha and hCG-beta subunits. An hCG preparation with an activity of $13000 \mathrm{i} . \mathrm{u} . / \mathrm{mg}$ by bioassay and $7500 \mathrm{i} . \mathrm{u} . / \mathrm{mg}$ by radioimmunoassay was supplied by $\mathrm{AB}$ Leo, Sweden, and the hCG-alpha and -beta subunits and their antisera (SA6 and SB6) were provided by NIAMDD, National Institutes of Health, Bethesda, U.S.A. Antisera to the 3 compounds were coupled directly to $\mathrm{CNBr}$-activated ultrafine Sephadex particles (Wide, 1969). The purified preparations of hCG and its subunits were labelled with ${ }^{125} \mathrm{I}$ by the chloramine-T technique (Greenwood, Hunter \& Glover, 1963). The 2nd International Standard for hCG was used as a reference preparation in the hCG assays of the placental extracts before chromatography. The sensitivity of the hCG assays was about 0.1 mi.u. per test tube. The assays were made as 6-point assays with 2 replicates at each dose level with a log dose interval of 0.301 for the standard and the unknown.

\section{Calculation of results}

The results and tests of validity of the assays were calculated according to Gaddum (1953). In the bioassays the response parameter was the logarithm of the mouse uterine weight and for the radioimmunoassays it was the logit value. Text-figure 1 was constructed from the bioassay results using a method of moving averages (Wallis \& Roberts, 1957).

\section{Haemagglutination-inhibition test}

Nine acetone-ether-dried placental preparations, from placentae plus subplacentae taken between Days 11 and 65 of gestation, were made up in a phosphate buffer at a concentration equivalent to $24 \mathrm{mg}$ wet weight of tissue per ml. Solutions were serially diluted, and aliquots of $0.1 \mathrm{ml}$ were tested in a haemagglutination-inhibition test using antiserum to the beta subunit of ovine luteinizing hormone and sheep red blood cells coated with hCG (Hodgen \& Ross, 1974). Controls, identical to the test solution except for the omission of the antiserum, were included with every test. In a second experiment, extracts prepared from individual placentae and their subplacentae were tested separately. The smallest amount of hCG which gives complete inhibition is $0.03 \mathrm{i} . \mathrm{u} . / \mathrm{ml}$.

\section{Neutralization of biological activity}

Experiments were performed to see whether the gonadotrophic activity of guinea-pig 
placental extracts could be neutralized by an anti-hCG serum. The antiserum used was raised against a commercial preparation having a biological activity of $5000 \mathrm{i} . \mathrm{u} . / \mathrm{mg}$ (Gonadex: Leo). Placentae plus subplacentae from animals at Days 9, 18, 36 and 63 of gestation and the hCG standard were assayed with the addition of anti-hCG serum or with normal rabbit serum (NRS) at a concentration of $15 \mu \mathrm{l} /$ total dose/mouse.

\section{Results}

\section{Assay of placentae and subplacentae}

The concentration of biologically active gonadotrophin in placental material (placenta plus subplacenta), from 60 guinea-pigs between Days 9 and 63 gestation, is shown in Text-fig. 1 . Estimates of potency and their $95 \%$ fiducial limits per $\mathrm{g}$ wet weight of tissue were calculated. No significant departure from parallelism or linearity was observed between the log dose and log response of the placental extracts and the hCG standard. An index of precision $(\lambda)$ was calculated for each assay (Gaddum, 1931): the median value for $\lambda$ was 0.046 (range $0.033-0.065$ ) in the bioassays, and corresponding values for the radioimmunoassay were 0.031 with a range of $0.02-0.06$.

With the exception of placentae and subplacentae obtained on Days 9 and 11, when material from several pregnant animals was combined before being extracted, all other observations relate to placental material from individual guinea-pigs. The highest mean gonadotrophin concentration occurred on Day 18 of pregnancy (Text-fig. 1). In spite of considerable variation there was a 'peak period' between Days 17 and 20 when values were significantly $(P<0.01)$ higher (mean 3.61 i.u. hCG per g) than between Days 9 and 16 (1.17 i.u. hCG per g) and between Days 21 and 30 ( 0.98 i.u. hCG per g). After Day 30 all values were below 0.63 i.u. hCG per g.

Placentae and subplacentae from 7 animals, killed at various times during pregnancy, were

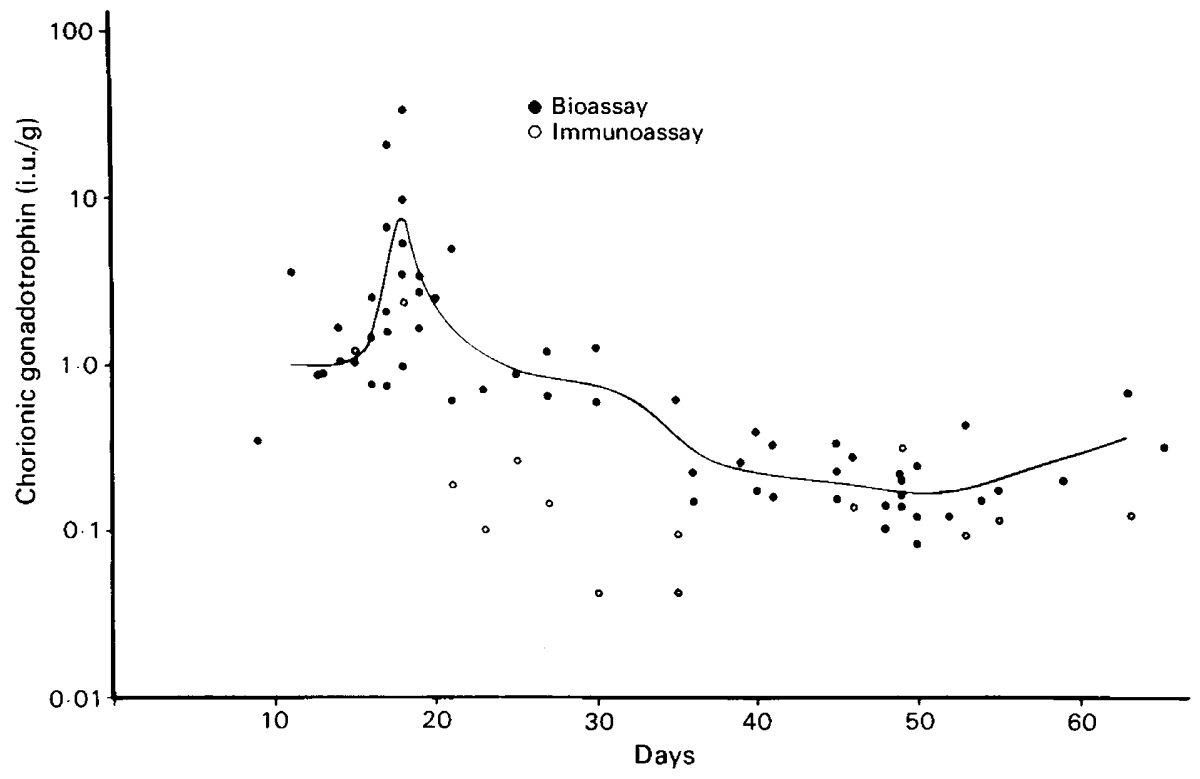

Text-fig. 1. Gonadotrophin concentration in extracts of placentae plus subplacentae from 60 guinea-pigs between Days 9 and 63 of gestation. The curve is constructed from bioassay data (O). Immunoassay results are also shown $(0)$. 
bioassayed separately (Table 1). No significant difference in the concentration of gonadotrophin in the two tissues was found (paired sample $t$ test, $P=0.5$ ).

Table 1. Concentration of biologically active gonadotrophin in the placentae and subplacentae of 7 guinea-pigs

\begin{tabular}{|c|c|c|c|}
\hline \multirow{2}{*}{$\begin{array}{c}\text { Animal } \\
\text { no. }\end{array}$} & \multirow{2}{*}{$\begin{array}{l}\text { Days of } \\
\text { gestation }\end{array}$} & \multicolumn{2}{|c|}{ Bioassay (i.u. hCG/g) } \\
\hline & & Subplacentae & Placentae \\
\hline 1 & 18 & $0.89(0.81-0.98)$ & $1.80(1.5-2 \cdot 1)$ \\
\hline 2 & 19 & $1.10(1.0-1 \cdot 3)$ & $2.00(1.6-2.4)$ \\
\hline 3 & 45 & $0.31(0.27-0.36)$ & $0.15(0.13-0.17)$ \\
\hline 4 & 46 & $0.21(0.19-0.23)$ & $0.30(0.23-0.39)$ \\
\hline 5 & 49 & $0.28(0.25-0.31)$ & $0.15(0.13-0.17)$ \\
\hline 6 & 53 & $0.54(0.46-0.61)$ & $0.38(0.33-0.43)$ \\
\hline 7 & 63 & $0.95(0.82-1.1)$ & $0.54(0.47-0.64)$ \\
\hline
\end{tabular}

Values are medians with the $95 \%$ fiducial limits given in parentheses.

The concentration of gonadotrophin in 14 placental extracts was estimated by radioimmunoassay and there was no statistically significant difference in parallelism between the hCG standard and the extracts. Ten of these placentae were also bioassayed; the results obtained showed that there was considerably less immunological CG activity than bioactivity. However, the pattern of gonadotrophin concentration was similar to that obtained with the bioassays and the highest value, equivalent to 2.3 i.u. hCG/g occurred on Day 18 of pregnancy (Text-fig. 1).

\section{Haemagglutination-inhibition test}

The antiserum to ovine LH was neutralized by and agglutination was inhibited with extracts from placentae of 9 guinea-pigs. The reactions were recorded as complete inhibition (+), partial inhibition $( \pm)$ and no inhibition ( $(-)$. The amount of placental extract needed to produce complete inhibition varied from 3 to $24 \mathrm{mg}$ per $\mathrm{ml}$ for the 9 placentae. The immunological activity, expressed in i.u. hCG equivalents per $\mathrm{g}$ fresh tissue, was calculated and compared with the bioassay results (Table 2). There was a significant correlation between the results of the 2 assay methods $(r=0.942)$. The highest haemagglutination-inhibition activity was found in extracts from placentae early in pregnancy.

Table 2. Haemagglutination-inhibition test reactions (complete $(+)$, partial $( \pm)$, none $(-))$ with 9 guineapig placental extracts

\begin{tabular}{|c|c|c|c|c|c|c|c|c|}
\hline \multirow{2}{*}{$\begin{array}{c}\text { Guinea-pig } \\
\text { no. }\end{array}$} & \multirow{2}{*}{$\begin{array}{l}\text { Days of } \\
\text { gestation }\end{array}$} & \multicolumn{5}{|c|}{ Concentration of placental extracts $(\mathrm{mg} / \mathrm{ml})$} & \multirow{2}{*}{$\begin{array}{l}\text { Immunological } \\
\text { activity (i.u./g) }\end{array}$} & \multirow{2}{*}{$\begin{array}{l}\text { Bioassay* } \\
\text { (i.u./g) }\end{array}$} \\
\hline & & 24 & 12 & 6 & 3 & 1.5 & & \\
\hline $4 c$ & 11 & + & + & + & + & - & 10 & $3.6 \quad(3.3-3.9)$ \\
\hline 69 & 17 & + & + & \pm & - & - & $3 \cdot 6$ & $0.73(0.63-0.82)$ \\
\hline 41 & 20 & + & + & + & \pm & - & 7 & $2.4 \quad(2 \cdot 1-2 \cdot 7)$ \\
\hline 21 & 27 & + & + & - & - & - & $2 \cdot 1$ & $1.1 \quad(0.91-1.3)$ \\
\hline 13 & 36 & + & \pm & - & - & - & 1.8 & $0.21(0.18-0.24)$ \\
\hline 15 & 49 & + & \pm & - & - & - & 1.8 & $0.19(0.17-0.20)$ \\
\hline 16 & 50 & + & \pm & - & - & - & 1.8 & $0.23(0.21-0.26)$ \\
\hline 17 & 59 & + & \pm & - & - & - & 1.8 & $0.19(0.17-0.21)$ \\
\hline 87 & 65 & + & + & \pm & - & - & $3 \cdot 6$ & $0.62(0.37-0.73)$ \\
\hline
\end{tabular}

* The $95 \%$ fiducial limits of the bioassay are given in parentheses. 
Table 3 shows that immunoreactive material was present in the placenta and subplacenta, with less subplacental extract being needed to inhibit agglutination than an extract made from the associated placenta.

Table 3. Results of haemagglutination-inhibition tests and bioassays on extracts from 3 guinea-pig placentae and their associated subplacentae

\begin{tabular}{cccccc}
\hline & \multicolumn{2}{c}{ Haemagglutination-inhibition test } & \multicolumn{2}{c}{ Bioassay* } \\
\cline { 2 - 3 } \cline { 5 - 6 } $\begin{array}{c}\text { Days of } \\
\text { gestation }\end{array}$ & $\begin{array}{c}\text { Placenta } \\
\text { (i.u./g) }\end{array}$ & $\begin{array}{c}\text { Subplacenta } \\
\text { (i.u./g) }\end{array}$ & & $\begin{array}{c}\text { Placenta } \\
\text { (i.u./g) }\end{array}$ & $\begin{array}{c}\text { Subplacenta } \\
\text { (i.u./g) }\end{array}$ \\
\hline 45 & 0.79 & 1.6 & & $0.15(0.13-0.17)$ & $0.31(0.27-0.36)$ \\
53 & 3.0 & 6.0 & & $0.38(0.33-0.43)$ & $0.54(0.46-0.61)$ \\
55 & 1.5 & 3.0 & $0.17(0.15-0.19)$ & $0.16(0.14-0.18)$ \\
\hline
\end{tabular}

* The $95 \%$ fiducial limits are given in parentheses.

\section{Chromatographic studies}

After gel chromatographic separation of guinea-pig placental extracts most of the activity determined by the hCG radioimmunoassay was found in the eluate corresponding to $K_{\mathrm{av}}=0 \cdot 40$. The peak activity of the hCG-alpha subunit assay was found about $K_{\mathrm{av}}=0.70$ and that of the hCG-beta subunit assay about $K_{\text {av }}=0.54$. The peak activity for purified hCG, hCG-alpha subunit and hCG-beta subunit was detected at $K_{\mathrm{av}}$ values of $0.40,0.63$ and 0.49 respectively.

\section{Neutralization of biological activity}

Table 4 shows the effect of an anti-hCG serum upon the biological activity of the hCG standard preparation and upon the placental extracts from 4 guinea-pigs. The biological effect of all these preparations in the mouse uterus assay was significantly suppressed by the anti-hCG serum.

Table 4. Neutralization of gonadotrophic activity of the hCG standard and in placental extracts from 4 guinea-pigs by an anti-hCG serum ( $15 \mu \mathrm{l} /$ mouse $)$

\begin{tabular}{|c|c|c|c|c|c|}
\hline \multirow[b]{2}{*}{ Material } & \multirow[b]{2}{*}{ Dose } & \multirow[b]{2}{*}{$\begin{array}{l}\text { No. of } \\
\text { animals }\end{array}$} & \multicolumn{2}{|c|}{ Mouse uterine weight (mg) } & \multirow{2}{*}{$\begin{array}{c}\text { Statistical } \\
\text { comparison } \\
\text { between } \\
\text { groups }\end{array}$} \\
\hline & & & $\begin{array}{c}\text { Anti-hCG } \\
\text { serum }\end{array}$ & $\begin{array}{l}\text { Normal rabbit } \\
\text { serum }\end{array}$ & \\
\hline Saline + NRS & $3 \mathrm{ml}$ & 10 & - & $10 \cdot 0 \pm 0.68$ & \\
\hline hCG standard & $\begin{array}{l}0.0625 \text { i.u. } \\
0.125 \text { i.u. } \\
0.25 \text { i.u. }\end{array}$ & $\begin{array}{l}10 \\
10 \\
10\end{array}$ & $\begin{array}{r}7.5 \pm 0.58 \\
7.5 \pm 0.88 \\
10.7 \pm 0.92\end{array}$ & $\begin{array}{l}12.4 \pm 1.08 \\
25.0 \pm 3.63 \\
54.3+7.54\end{array}$ & $P<0.0001$ \\
\hline $\begin{array}{l}\text { Guinea-pig plac } \\
9 \text { days }\end{array}$ & $\begin{array}{l}10 \mathrm{mg} \\
20 \mathrm{mg}\end{array}$ & $\begin{array}{l}5 \\
5\end{array}$ & $8.0 \pm 0.80$ & $13 \cdot 5 \pm 2 \cdot 27$ & $P<0.001$ \\
\hline 18 days & $\begin{array}{r}25 \mathrm{mg} \\
50 \mathrm{mg} \\
100 \mathrm{mg}\end{array}$ & $\begin{array}{l}5 \\
5 \\
5\end{array}$ & $\begin{array}{r}7.6 \pm 0.34 \\
8.1 \pm 0.48 \\
10.2 \pm 1.91\end{array}$ & $\begin{array}{l}10.1 \pm 0.96 \\
14.8 \pm 1.74 \\
27.7 \pm 5.60\end{array}$ & $\begin{array}{l}P<0.0005 \\
P<0.0001\end{array}$ \\
\hline 36 days & $\begin{array}{l}400 \mathrm{mg} \\
800 \mathrm{mg}\end{array}$ & $\begin{array}{l}5 \\
5\end{array}$ & $\begin{array}{l}6.7 \pm 0.25 \\
6.6 \pm 0.23\end{array}$ & $\begin{array}{r}9.7 \pm 0.96 \\
12.6 \pm 1.21\end{array}$ & $P<0.0001$ \\
\hline 63 days & $\begin{array}{r}80 \mathrm{mg} \\
160 \mathrm{mg}\end{array}$ & $\begin{array}{l}5 \\
5\end{array}$ & $\begin{array}{l}6.7 \pm 0.27 \\
8.4 \pm 0.82\end{array}$ & $\begin{array}{l}12.0 \pm 1.20 \\
23.1 \pm 2.76\end{array}$ & $P<0.0001$ \\
\hline
\end{tabular}

Values are mean \pm s.d. 


\section{Discussion}

It has been postulated that the guinea-pig conceptus produces a luteotrophic substance which maintains the corpus luteum of pregnancy. The nature of this luteotrophin has remained controversial and not so far been shown to be related to CG of the human placenta. It has been suggested that in the sheep the uterine luteolysin exerts its effect upon the ovary via a veno-arterial pathway (Barrett et al., 1971; Ginther, 1974). Poyser \& Maule Walker (1979) suggested that this may be the route by which placental luteotrophin exerts its effect upon the ovary of the guinea-pig.

This investigation has shown that a gonadotrophin is present in the subplacenta and placenta of the guinea-pig from the 10th day of pregnancy until parturition. Maximum concentrations of gonadotrophin in tissue extracts, estimated by bioassay and radioimmunoassay, occurred during the 3 rd week of gestation (Text-fig. 1). Values after the peak were consistently low and from the 4th week of pregnancy did not exceed the equivalent of $1.0 \mathrm{i} . \mathrm{u}$. hCG per $\mathrm{g}$. The fall in concentration of guinea-pig placental gonadotrophin coincides with a decline in ovarian serum progesterone and rising levels of serum placental progesterone (Heap, Illingworth \& Perry, 1973). Bioassays of individual placentae and subplacentae did not show any significant systematic difference in the gonadotrophin concentration in the two tissues. The level of gonadotrophin in the guinea-pig placenta plus subplacenta is about $1 / 100$ th of that found in the human placenta (Hobson, 1972), but if the gonadotrophin reaches the ovary via a local veno-arterial pathway such a low level may be sufficient to maintain the corpus luteum.

Our results provide evidence that the nature of the luteotrophin in the guinea-pig placenta is similar to CG extracted from human and non-human placentae. This is based upon results from radioimmunoassays and bioassays, in which there was no lack of parallelism or linearity of response between the hCG standard and the placental extracts, and the ability of an hCG antiserum to neutralize the biological activity of the hCG standard and of the placental extracts. Both the hCG standard and the guinea-pig placental extracts cross-reacted in the haemagglutination-inhibition test in which an antiserum to the beta subunit of ovine $\mathrm{LH}$ was used. After gel chromatography the components in the placental extracts, active in the hCG, hCG-alpha and hCG-beta subunit radioimmunoassays, were eluted in positions similar to those of purified hCG and its subunits. This indicates that in women and guinea-pigs these components are of a similar molecular size. Placental extracts from several mammalian species, made and examined by the same methods, behave similarly (Wide \& Hobson, 1978; Hobson \& Wide, 1981).

Bland \& Donovan (1969) concluded that the guinea-pig placenta appears to produce a systemically active substance capable of neutralizing the luteolytic abilities of the uterus. Bolt (1979) showed that hCG was able to reduce the luteolytic effect of prostaglandin F-2 $\alpha$ in the sheep. It is possible that a gonadotrophic substance, extracted from the guinea-pig placenta and shown to resemble hCG in a number of ways, may have a similar effect in guinea-pigs.

This research was supported by the Swedish Medical Research Council (Grant No. 3145) and Organon Teknika, England. We thank Mrs J. Flockhart, Miss Rita Ghione and Mr Christer Bengtsson for technical assistance and NIAMDD, NIH, Bethesda, for the materials indicated.

\section{References}

Allen, W.R. \& Moor, R.M. (1972) The origin of the equine endometrial cups. I. Production of PMSG by fetal trophoblast cells. J. Reprod. Fert. 29, 313-316.

Astwood, E.B. (1953) Tests for luteotrophin. Ciba Fdn. Colloq. Endocrinology, 5, 74-89.
Astwood, E.B. \& Greep, R.O. (1938) A corpus luteum stimulating substance in the rat placenta. Proc. Soc. exp. Biol. Med. 38, 713-716.

Barrett, S., Blockey, M.A. de B., Brown, J.M., Cumming, I.A., Goding, J.R., Mole, B.J. \& Obst, J.M. (1971) 
Initiation of the oestrous cycle in the ewe by infusions of $\mathrm{PGF}_{2 a}$ to the autotransplanted ovary. J. Reprod. Fert. 24, 136-137, Abstr.

Bland, K.P. \& Donovan, B.T. (1969) Observations on the time of action and the patterns of the uterine luteolytic effect of the guinea pig. J. Endocr. 43, 259-264.

Blandau, R.J. \& Young, W.C. (1939) The effects of delayed fertilization on the development of the guinea pig ovum. Am. J. Anat. 64, 303-329.

Bolt, D.J. (1979) Reduction by human chorionic gonadotrophin of the luteolytic effect of prostaglan$\operatorname{din} \mathrm{F}_{2} \alpha$ in ewes. Prostaglandins 18, 387-396.

Catchpole, H.R. \& Lyons, W.R. (1934) The gonad stimulating hormone of pregnant mares. Am.J.Anat. 55, 167-227.

Courrier, R., Kehl, R. \& Raynaud, R. (1929) Neutralisation de l'hormone folliculaire chez la femelle gestante castree. C. r. Séanc. Soc. Biol. 100, 1103-1105.

Davies, J., Dempsey, E.W. \& Amoroso, E.C. (1961) The subplacenta of the guinea pig: development, histology and histochemistry. J. Anat. 95, 457-473.

Gaddum, J.H. (1931) The determination of vitamin A in cod-liver oils. Statistical examination of the results. Biochem. J. 25, 1113-1119.

Gaddum, J.H. (1953) Simplified mathematics for bioassays. J. Pharm. Pharmac. 5, 345-358.

Ginther, O.J. (1974) Internal regulation of physiological processes through local venoarterial pathways: A review. J. Anim. Sci. 39, 550-564.

Greenwood, F.C., Hunter, W.M. \& Glover, J.S. (1963) The preparation of ${ }^{131}$ I-labelled human growth hormone of high specific radioactivity. Biochem. $J$. 89, 114-123.

Haour, F., Tell, M.G. \& Sanchez, P. (1976) Mise en évidence et dosage d'une gonadotropin chorionique chez le rat (rCG). C.r. hebd. Séanc. Acad. Sci., Paris D 282, 1183-1186.

Heap, R.B., Perry, J.S. \& Rowlands, I.W. (1967) Corpus luteum function in the guinea-pig; arterial and luteal progesterone levels, and the effects of hysterectomy and hypophysectomy. J. Reprod. Fert. 13, 537-553.

Heap, R.B., Illingworth, D.V. \& Perry, J.S. (1973) The secretory activity of the corpus luteum in the guinea pig and its role in the establishment and maintenance of pregnancy. In Le Corps Jaune, pp. 69-80. Eds R. Denamur \& A. Netter. Masson, Paris.

Herrick, E.H. (1928) Duration of pregnancy in guinea pigs after removal and also after transplantation of ovaries. Anat. Rec. 39, 193-200.

Hobson, B.M. (1971) Production of gonadotrophin, oestrogens and progesterone by the primate placenta. Adv. Reprod. Physiol. 5, 67-102.
Hobson, B.M. (1972) Gonadotrophin concentration in the placentae of man, the rhesus monkey and the marmoset. Folia primat. 18, 35-40.

Hobson, B.M. \& Wide, L. (1981) The similarity of chorionic gonadotrophin and its subunits in term placentae from man, apes, old and new world monkeys and a prosimian. Folia primat. 35, 51-64.

Hodgen, G.D. \& Ross, G.T. (1974) Pregnancy diagnosis by haemagglutination inhibition test for urinary macaque chorionic gonadotropin (mCG). $J$. clin. Endocr. Metab. 38, 927-930.

Lacroix, M.C. \& Martal, J. (1979) Mise en évidence et evolution d'une gonadotrophin chorionique chez la Brebis. C.r. hebd. Séanc. Acad. Sci. Paris D 288, 771-774.

Laurent, T.C. \& Killander, J. (1964) A theory of gel filtration and its experimental verification. $J$. Chromat. 14, 317-330.

Linkie, D.M. \& Niswender, G.D. (1973) Characterization of rat placental luteotropin. Biol. Reprod. 8, 48-57.

Okker-Reitsma, G.H. (1978) Secretion of a gonadotrophin by the mouse placenta in vitro. In Comparative Endocrinology, pp. 85-86. Eds P. J. Gaillard \& H. H. Boer. Elsevier, Amsterdam.

Okker-Reitsma, G.H. \& Wilson, G.L. (1980) Evidence for a biphasic pattern in gonadotrophin secretion by the mouse placenta in vitro. J. Steroid Biochem. 12, 97-99.

Phoenix, C.H. (1970) Guinea pigs. In Reproduction and Breeding Techniques for Laboratory Animals, pp. 244-257. Ed. E. S. E. Hafez. Lea \& Febiger, Philadelphia.

Poyser, N.L. \& Maule Walker, F.M. (1979) Antiluteolytic effect of the embryo. In Maternal Recognition of Pregnancy (Ciba Fdn. Symp. No. 64), pp. 261-292. Ed. J. Whelan. Excerpta Medica, Amsterdam.

Wide, L. (1969) Radioimmunoassay employing immunosorbents Acta endocr., Copenh., Suppl. 142, 207221.

Wide, L. \& Hobson, B.M. (1978) Chromatographic studies on a chorionic gonadotropic activity in the placenta of the rat, mouse and hamster. Uppsala $J$. med. Sci. 83, 1-6.

Wide, L. \& Wide, M. (1979) Chorionic gonadotrophin in the mouse from implantation to term. J. Reprod. Fert. 57, 5-9.

Wide, L., Hobson, B.M. \& Wide, M. (1980) Chorionic gonadotropin in rodents. In Chorionic Gonadotropin, pp. 37-51. Ed. S. J. Segal, Plenum Press, New York.

Wallis, W.A. \& Roberts, H.V. (1957) Statistics: A New Approach. Methuen, London.

Received 10 August 1981 